\title{
PERANCANGAN DAN ANALISA PENGGELARAN LTE PADA FREKUENSI 700 MHZ DENGAN METODE ADAPTIF MODULATION CODING UNTUK IMPLEMENTASI DIGITAL DIVIDEND DI WILAYAH SUB-URBAN DAN RURAL KABUPATEN BANYUMAS
}

\section{DESIGN AND ANALYSIS OF LTE DEPLOYMENT ON 700 MHZ FREQUENCY WITH ADAPTIVE MODULATION CODING METHOD FOR DIGITAL DIVIDEND IMPLEMENTATION IN SUB- URBAN AND URBAN AREA OF BANYUMAS REGENCY}

\author{
Ade Wahyudin ${ }^{1}$, Sakinah ${ }^{2}$ \\ ${ }^{1}$ Program Studi Teknik Telekomunikasi Sekolah Tinggi Teknologi Telematika Telkom Purwokerto, \\ ${ }^{2}$ Fakultas Teknik, Jurusan Teknik Elektro Universitas Jendral Achmad Yani \\ 1adewahyudin@st3telkom.ac.id,_杰akinasakino@gmail.com
}

\begin{abstract}
Abstrak
Rencana Implementasi analouge switchover to TV digital akan menjadikan solusi dalam menyikapi terbatasnya alokasi spektrum radio untuk memenuhi pengembangan serta pemerataan mobile broadband di Indonesia. Pemanfaatan frekuensi $700 \mathrm{MHz}$ untuk teknologi untuk teknologi LTE (Long Term Evolution) akan memberikan dampak yang positif terhadap bagi penyebaran layanan telekomunikasi terutama pada wilayah rural yang memiliki penetrasi broadband yang kecil, sehingga mampu mengurangi kesenjangan digital antara wilayah urban, sub-urban dan rural. Perancangan jaringan LTE FDD pada frekuensi $700 \mathrm{MHz}$ band menggunkan skenario bandwidth $15 \mathrm{MHz}$ dan $10 \mathrm{MHz}$ di wilayah Sub-Urban dan Rural Kabupaten Banyumas yang dilakukan dengan menggunakan pendekatan coverage, kapasitas dan simulasi menggunakan software Atoll untuk menganalisa performa jaringan LTE. Pada pendekatan coverage dengan menggunakan model propagasi Okumura-Hatta membutuhkan 13 e_NodeB untuk dapat mencakup seluruh wilayah pengamatan. Sedangkan pendekatan kapasitas pada skenario bandwidth $10 \mathrm{MHz}$ cembutuhkan 8 e_NodeB (MIMO 2x2) dan 4 e_NodeB (MIMO 3x3) dan pada skenario bandwith $15 \mathrm{MHz}$ membutuhkan 4 e_NodeB baik menggunakan MIMO $2 \times 2$ maupun MIMO $3 \times 3$. Berdasarkan simulasi kualitas sinyal, didapatkan nilai rata-rata RSRP $-72.2 \mathrm{~dB}$ dan SINR rata-rata 6.83. Sedangkan nilai index CQI sebesar 7.17, sehingga perangkat user yang dapat menerima layanan adalah yang memiliki spesifikasi modulasi 64QAM dengan code rate 466 dan efisiensi 2.7. Pada parameter nilai throughput memiliki perbedaaan antara kedua skenario, dimana bandwidth 15 MHz memiliki throughput hingga $52 \mathrm{Mbps}$ sedangkan bandwidth $10 \mathrm{MHz}$ hanya $16 \mathrm{Mbps}$.
\end{abstract}

Kata kunci: Long Term Evolution, Atoll, Thrpughput, Okumura Hatta, SINR, RSRP

\begin{abstract}
The planning of analouge switch over to TV digital implementation will become a solution to deal with limited radio spectrum allocation to meet the development and the distribution of mobile broadband in Indonesia. The utilization of $700 \mathrm{MHz}$ band frequency for LTE technology will give positive impact for telecommunication services deployment especially in rural area which has low broadband penetration, so as to reduce the digital divide between urban, sub-urban and rural area. Long Term Evolution FDD network design at frequency $700 \mathrm{MHz}$ using bandwidth $10 \mathrm{MHz}$ and 15 $\mathrm{MHz}$ scenario at sun-urban and rural area in Banyumas Regency which is done by using approach of
\end{abstract}


coverage, capacity and softwareAtoll simulation to analysis LTE network performance. On coverage approach by using Okumura-Hatta Propagation Model require 13 e_NodeB to cover the observation area. While the approach of capacity in $10 \mathrm{MHz}$ bandwidth scenario requires 8 e_NodeB (MIMO 2x2) and 4 e_NodeB (MIMO 3x3). While at At $15 \mathrm{MHz}$ bandwidth scenario needs 4 e_NodeB either using 2x2 MIMO and 3x3 MIMO. Based on the simulation of signal quality, the average value of RSRP is $-72.2 \mathrm{~dB}$ and the SINR average is 6.83. While CQI index value is 7.17, so that the user device which can receive the service are those that have specifications 64QAM modulation with rate code 466 and efficiency 2.7. In parameter thrpughput have differences between the two skenarios, where the bandwidth of $15 \mathrm{MHz}$ has a thrpughput of up to $52 \mathrm{Mbps}$ while the bandwidth of $10 \mathrm{MHz}$ is only $16 \mathrm{Mbps}$.

\section{Keywords: Long Term Evolution, Atoll, Thrpughput, Okumura Hatta, SINR, RSRP}

\section{PENDAHULUAN}

Dewasa ini layanan TIK (Teknologi Informasi dan Komunikasi) mengubah pola hidup individu, sosial, dan bisnis. Telah banyak penelitian yang memperlihatkan bagaimana TIK dapat berpengaruh secara signifikan terhadap perekonomian mikro maupun makro suatu negara. Selain itu bermunculannya berbagai macam layanan teknologi multimedia berkecepatan tinggi seperti Mobile TV, video conference, video streaming membutuhkan dukungan dari teknologi broadband yang mampu mendukung layanan tersebut.

Dengan kondisi geografis Indonesia yang sangat luas, terdiri dari kurang lebih 13.000 pulau menyebabkan percepatan perluasan dan pengembangan infrastruktur broadband menjadi sedikit lambat. Solusi tepat dalam pengembangan broadband di Indonesia adalah dengan kebijakan pengembangan mobile broadband. Mobile broadband menjanjikan biaya penyelenggaraan yang lebih murah serta skala ekonomi yang lebih baik dibandingkan dengan pengembangan fixed broadband yang memiliki jangkauan terbatas dan investasi yang jauh lebih mahal.

Untuk menyiapkan hal tersebut, terdapat kekhawatiran mengenai kurangnya alokasi spektrum frekuensi radio untuk memenuhi kebutuhan pengembangan mobile broadband di Indonesia. Sama seperti halnya beberapa negara di dunia yang juga mengalami permasalahan kekurangan spektrum frekuensi radio untuk memberikan layanan suara, teks, dan internet kepada pelanggannya. Fenomena kekurangan spektrum tersebut disebut "spectrum crunch" [1].

Salah satu solusi untuk masalah di atas yaitu dengan adanya pemanfaatan pita frekuensi yang saat ini dipakai oleh TV Analog yaitu pada range frekuensi $694-820 \mathrm{MHz}$. Proses migrasi TV Analog menuju TV Digital (digital dividend) memberikan peluang yang sangat menjanjikan bagi operator untuk menggunakan frekuensi $700 \mathrm{MHz}$ sebagai frekuensi kerja LTE. Salah satu keuntungan dari penggunaan frekuensi $700 \mathrm{MHz}$ tersebut yaitu radius sel yang lebih luas.

Berdasarkan laporan konsultan BCG (Boston Consulting Group), alokasi pita $700 \mathrm{MHz}$ kepada mobile broadband akan memberikan perbedaan signifikan untuk pembangunan di wilayah pedesaan, memberikan lebih dari 9,7 juta lebih pelangggan pada tahun 2020. Hal ini merepresentasikan $22 \%$ peningkatan di atas ekspansi baseline yang diperhitungkan selama periode dimaksud [1].

Indonesia akan mendapatkan manfaat ekonomi substansial bilamana memilih untuk mengalokasikan $700 \mathrm{MHz}$ kepada mobile broadband. Apakah diukur dalam GDP (Gross Domestic Product), pendapatan pemerintah, penciptaan bisnis maupun lapangan pekerjaan baru. Hal ini dapat memberikan manfaat lebih produktif dibandingkan mengalokasikan pita ini untuk bidang lainnya seperti penyiaran. Oleh karena itu, penelitian ini akan membahas mengenai perencanaan dan 
analisis penggelaran layanan 4G LTE pada pita frekuensi $700 \mathrm{MHz}$ dalam rangka implementasi frekuensi digital dividend.

Oleh sebab itu diperlukan suatu kajian mengenai perancangan jaringan 4G LTE pada frekuensi $700 \mathrm{MHz}$, di daerah rural. Karena karakteristik penggunaan frekuensi $700 \mathrm{MHz}$ sangat sesuai dengan wilayah rural yang memiliki wilayah yang luas, serta secara bisnis sangat menguntungkan. Investasi LTE di wilayah rural akan lebih hemat karena pembangunan e_NodeB akan sangat sedikit bila menggunakan frekuensi $700 \mathrm{MHz}$ dibandingkan dengan penggunaan frekuensi yang lebih tinggi [2].

Untuk menciptakan jaringan LTE yang handal dibutuhan perencanaan yang matang baik secara jangkauan dan kapasitas, oleh karena itu penulis menggunaka software Atoll. Atoll adalah salah satu software yang dapat digunakan untuk membangun simulasi perencanaan jaringan LTE. Dengan Atoll versi 3.2.1, perencanaan dapat dilakukan mulai dari core network, base station hingga user equipment. Teknologi yang didukung pada software atoll adalah GSM/GPRS/EDGE, CDMA2000/EV-DO, TD-SCDMA, UMTS/HSPA, WiMAX, Microwave Links, LTE/LTE-A, WIFI. Atoll mampu untuk melakukan desain jaringan microwave berdasarkan standar industri, rekomendasi ITU, dan standar operator.

Pada penelitian penulis sebelumnya yang berjudul "Perencanaan dan Analisis Tekno Ekonomi Migrasi UMTS Menuju LTE Pada Frekuensi 700 MHz di DKI Jakarta" menjelaskan mengenai proses transisi dari jaringan UMTS menuju LTE di dearah dense urban, DKI Jakarta. Namun penelitian tersebut memiliki kekurangan yaitu penggunaan frekuensi $700 \mathrm{MHz}$ tidak optimal bila diterapkan didaerah dense urban. Atas dasar itu, penulis beinisiatif untuk mengangkat penelitian dengan judul "Perancangan dan analisa penggelaran LTE pada frekuensi $700 \mathrm{MHz}$ dengan metode Adaptif Modulation Coding untuk implementasi digital dividend di wilayah suburban dan rural Kabupaten Banyumas".

\section{METODOLOGI PENELITIAN}

Metode penelitian yang dilakukan dengan menggunakan pendekatan coverage (cakupan) dan capacity (kapasitas) dengan metode adaptif modulation coding serta simulasi radio planning menggunakan software Atoll versi 3.2.1.5838, seperti di ilustrasikan pada gambar 1. Proses simulasi perencanaan jaringan LTE Kabupaten Banyumas dengan menggunakan 2 skenario. Skenario Pertama adalah frekuensi $700 \mathrm{MHz}$ bandwidth $10 \mathrm{MHz}$ dan skenario kedua adalah 700 MHz bandwidth $15 \mathrm{MHz}$.

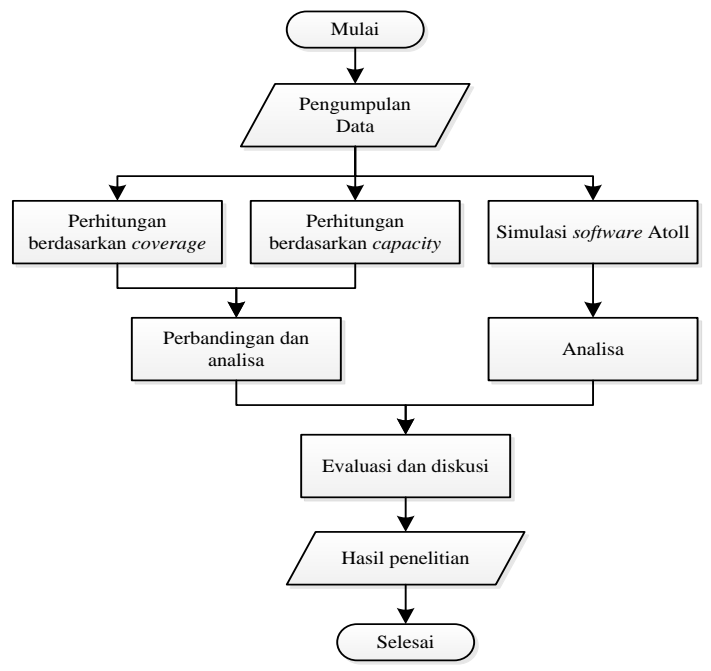

Gambar 1. Diagram Alir LTE Planning 


\subsection{Arsitektur Jaringan dan Teknologi Pendukung LTE}

Arsitektur LTE dikenal dengan suatu istilah SAE (System Architecture Evolution) yang menggambarkan suatu evolusi arsitektur dibandingkan dengan teknologi sebelumnya. Secara keseluruhan LTE mengadopsi teknologi EPS (Evolved Packet System). Di dalamnya terdapat tiga komponen penting yaitu UE (User Equipment), E-UTRAN (Evolved UMTS Terrestial Radio Access Network), dan EPC (Evolved Packet Core). [3]

Pada jaringan LTE ada beberapa parameter yang dapat diukur untuk menentukan Key Performance Indicator (KPI), seperti RSRP, SINR, QCI Index dan Thrpughput.

\section{RSRP}

Kuat sinyal yang diterima User Equpment (UE) pada tehnologi LTE disebut dengan Reference Signal Received Power (RSRP). Nilai RSRP yang merupakan power sinyal reference yang digunakan untuk menunjukan bagus tidaknya coverage jaringan pada suatu daerah.

Tabel 1. Rentang Nilai RSRP [4]

\begin{tabular}{|c|c|}
\hline Nilai & Keterangan \\
\hline$>=-71 \mathrm{dBm}$ & Very Good \\
\hline$<-71 \mathrm{dBm}$ to $<=-81 \mathrm{dBm}$ & Good \\
\hline$<-81 \mathrm{dBm}$ to $<=-91 \mathrm{dBm}$ & Normal \\
\hline$<-91 \mathrm{dBm}$ to $<=-101 \mathrm{dBm}$ & Bad \\
\hline$<-101 \mathrm{dBm}$ & Worst \\
\hline
\end{tabular}

\section{SINR}

Signal to Interference Noice Ratio (SINR) merupakan perbandingan kuat signal dibanding dengan interferensi sinyal dari sel lain. Parameter ini menunjukan level daya minimum dimana user masih bisa melakukan suatu panggilan.

Tabel 2. Rentang Nilai SINR [4]

\begin{tabular}{|c|c|}
\hline Nilai & Keterangan \\
\hline $16 \mathrm{~dB}$ to $30 \mathrm{~dB}$ & Good \\
\hline $1 \mathrm{~dB}$ to $15 \mathrm{~dB}$ & Normal \\
\hline$-10 \mathrm{~dB}$ to $0 \mathrm{dBm}$ & Bad \\
\hline
\end{tabular}

3. Radio bearer

Radio bearer merupakan Parameter yang mewakili nilai CQI Index yang digunakan. CQI Index merupakan parameter yang menunjukan jenis modulasi yang digunakan pada sistem jaringan LTE.

Tabel 3. LTE CQI Index [5]

\begin{tabular}{|c|c|c|c|}
\hline CQI index & modulation & code rate $\times 1024$ & efficiency \\
\hline 0 & \multicolumn{3}{|c|}{ out of range } \\
\hline 1 & QPSK & 78 & 0.1523 \\
\hline 2 & QPSK & 193 & 0.3770 \\
\hline 3 & QPSK & 449 & 0.8770 \\
\hline 4 & 16QAM & 378 & 1.4766 \\
\hline 5 & 16QAM & 490 & 1.9141 \\
\hline 6 & 16QAM & 616 & 2.4063 \\
\hline 7 & 64QAM & 466 & 2.7305 \\
\hline 8 & 64QAM & 567 & 3.3223 \\
\hline 9 & 64QAM & 666 & 3.9023 \\
\hline 10 & 64QAM & 772 & 4.5234 \\
\hline 11 & 64QAM & 873 & 5.1152 \\
\hline 12 & 256QAM & 711 & 5.5547 \\
\hline 13 & 256QAM & 797 & 6.2266 \\
\hline 14 & 256QAM & 885 & 6.9141 \\
\hline 15 & 256QAM & 948 & 7.4063 \\
\hline
\end{tabular}

4. Throughput

Throughput merupakan besaran kecepatan akses data yang didapat oleh user. 


\subsection{Konfigurasi Frekuensi APT 700 MHz FDD}

Dalam penelitian ini, menggunkan standar frekuensi $700 \mathrm{MHz}$ yang ditetapkan oleh APT (Asia Pacific Telecommunity). APT merupakan wireless forum yang menetapkan standar konfigurasi untuk frekuensi $700 \mathrm{MHz}$ dalam 2 Varian yaitu untuk FDD 2x45 MHz dan TDD 2x45MHz, keduanya mencakup jangkauan frekuensi 698-806 MHz.Untuk konfigurasi APT 700 FDD, memiliki passband bandwidth sebesar $45 \mathrm{MHz}$ dengan $10 \mathrm{MHz}$ duplex gap. Sebuah lower guard-band dialokasikan $5 \mathrm{MHz}$ antara 698-703 MHz, sedangkan $3 \mathrm{MHz}$ dialokasikan untuk upper guard band diantara 803-806 MHz. selain itu lower block (703 - $748 \mathrm{MHz}$ ) dialokasikan untuk transmisi Uplink mobile [6].

\subsection{Perencanaan berdasarkan pendekatan Coverage}

1. Penentuan Daerah Layanan

Penentuan daerah layanan dimaksudkan agar perencanaan yang dilakukan difokuskan berdasarkan data-data yang berkaitan dengan daerah tersebut. Daerah yang menjadi fokus dalam perencanaan jaringan LTE ini yaitu daerah kabupaten banyumas yang memiliki geotype rural. Bila dilihat dari data BPS luas wilayah kabupaten banyumas adalah 1327,4 $\mathrm{Km}^{2}$ [7], wilayah banyumas didominasi sub-urban dan rural, kecuali wilayah kota Purwokerto yang memiliki luas wilayah $38.4 \mathrm{~km}^{2}$. Sehingga wilayah layanan jaringan LTE pada penelitian ini adalah $1289 \mathrm{Km}^{2}$.

2. Perhitungan MAPL (Maximum Allowable Path Loss) [8]

MAPL dihitung berdasarkan arah uplink dan downlink. Berikut tahapan untuk menghitung nilai MAPL.

- MAPL Uplink

persamaan MAPL (Maximum Allowable Path Loss)

$M A P L_{\text {uplink }}=(P T+G T-B L)-(N F+T N+S I N R)-I M-C L+G R+M H A$ Gain

(1)

- MAPL Downlink

Sehingga didapat persamaan MAPL (Maximum Allowable Path Loss)

$M A P L_{\text {downlink }}=(P T+G T-C L)-(N F+T N+S I N R)-I M-C C O+G R-B L$

(2)

Dimana :

$\begin{array}{llll}P T & \text { : power transmit } & \text { SINR } & \text { : signal to interference and noise ratio } \\ G T & \text { : gain transmit } & I M & \text { : interference margin } \\ G R & \text { : gain receive } & B L & : \text { cable loss } \\ B L & \text { : bodyloss } & \text { CCO } & : \text { control channel overhead } \\ N F & \text { : noise figure } & \text { MHA Gain } & : \text { masthead amplifier gain } \\ T N & \text { : thermal noise } & & \end{array}$

3. Perhitungan Jari-jari dan Luas Sel [8]

Menghitung jari-jari sel diperlukan untuk menghitung pathloss dengan menggunakan metode Okumura-Hatta, yaitu :

$L_{U}=C_{1}+C_{2} \log (f)-13,82 \log \left(h_{b}\right)-C_{H}+\left[44,9-6,55 \log \left(h_{b}\right)\right] \log d$

Untuk daerah kecil dan sedang, faktor koreksinya yaitu :

$C_{H}=0,8+[1,1 \log (f)-0,7] * h_{m}-[1,56 \log (\mathrm{f})]$ 
Untuk daerah luas :

$C_{H}=\left[\begin{array}{l}8,29 *\left(\log \left(1,54 * h_{m}\right)\right)^{2}-1,1 \text { untuk } 150 \leq f \leq 200(\mathrm{MHz}) \\ 3,2 *\left(\log \left(11,75 * h_{m}\right)\right)^{2}-4,97 \text { untuk } 200 \leq f \leq 1500(\mathrm{MHz})\end{array}\right]$

Sehingga, radius sel maksimum yang bisa dicakup dimodelkan dengan persamaan berikut ini :

$d_{K m}=\log ^{-1}\left[\frac{M A P L-C_{1}-C_{2} \log (f)+13,82 \log \left(h_{b}\right)+C_{H}}{44,9-6,55 \log \left(h_{b}\right)}\right]$

Dimana :

$\mathrm{L}_{\mathrm{U}} \quad=$ Pathloss di area urban $(\mathrm{dB})$

$\mathrm{C}_{1}=\left[\begin{array}{c}69,55 \text { untuk } 400 \leq \mathrm{f} \leq 1500(\mathrm{MHz}) \\ 46,30 \text { untuk } 1500 \leq \mathrm{f} \leq 2000(\mathrm{MHz})\end{array}\right]$

$\mathrm{C}_{2}=\left[\begin{array}{c}26,16 \text { untuk } 400 \leq \mathrm{f} \leq 1500(\mathrm{MHz}) \\ 33,90 \text { untuk } 1500 \leq \mathrm{f} \leq 2000(\mathrm{MHz})\end{array}\right]$

$\mathrm{f} \quad=$ frekuensi $(\mathrm{MHz})$

$\mathrm{h}_{\mathrm{b}} \quad=$ tinggi antena Base Station $(\mathrm{km})$

$\mathrm{h}_{\mathrm{m}} \quad=$ tinggi antena Mobile Station $(\mathrm{km})$

$\mathrm{C}_{\mathrm{H}} \quad=$ faktor koreksi tinggi antenna

$\mathrm{d} \quad=$ jarak antara MS dan BS $(\mathrm{Km})$

Sedangkan untuk menentukan luas dari sel yang menggunakan trisectoral, dapat diperhitungkan dengan manggunakan persamaan berikut :

$$
L_{\text {cell }}=1,95 \times 2,6 \times d^{2}
$$

(7)

Dimana :

$$
\begin{array}{ll}
\mathrm{L}_{\text {cell }} & : \text { luas sel } \\
\mathrm{d} & : \text { jari-jari sel }(\mathrm{km})
\end{array}
$$

4. Perhitungan Jumlah Sel [8]

Untuk menentukan jumlah sel, dapat diperhitungkan dengan menggunakan persamaan berikut:

$$
\sum L T E \text { Cell }=\frac{L_{\text {Area }}}{L_{\text {Cell }}}
$$

Dimana :

¿LTE Cell : Jumlah sel LTE

\subsection{Perencanaan berdasarkan pendekatan capacity}

1. Estimasi Pelanggan Potensial

Analisa Jumlah pelanggan penting dilakukan agar kualitas layanan yang sudah dibangun nantinya mampu memenuhi kebeutuhan user yang tersebar di daerah yang direncanakan. Kabupaten Banyumas, berdasarkan data dari Badan Pusat Statistik (BPS), pada tahun 2015 memiliki jumlah penduduk 1.620.918 jiwa penduduk.[7]

Dengan menggunakan asumsikan bahwa pengguna ponsel yang aktif adalah penduduk dengan golongan usia dari 15 tahun hingga 64 tahun, serta berdasarkan data BPS 64\% penduduk kabupaten banyumas berada diwilayah sub-urban dan rural dan data pengguna LTE oleh operator. Oleh karena itu didapatkan bahwa pelanggan LTE potensial untuk penelitian ini adalah 110.509 pelanggan LTE. 
2. Klasifikasi Model Layanan

Layanan yang digunakan pada penelitian ini adalah VoIP, Video Phone, Video Conference, Real Time Gaming, Streaming Media, Signaling, Web Browsing, File Transfer dan email. Dari layanan yang digunakan tersebut, maka dilakukan perhitungan throughput per layanan dengan ketentuan berikut: [10]

Throughput $=$ Bearer rate $x$ session time $x$ session duty ratio $x(1 /(1-B L E R)$

(9)

Dimana, BLER adalah nilai block error yang masih bisa ditoleransi.

Tabel 4. Parameter Layanan LTE [10]

\begin{tabular}{|c|c|c|c|c|c|c|c|c|c|c|c|c|}
\hline \multirow[b]{2}{*}{ Traffic Parameters } & \multicolumn{5}{|c|}{ Uplink } & \multicolumn{5}{|c|}{ Downlink } & \multirow{2}{*}{$\mid \begin{array}{c}\text { Penetrati } \\
\text { on Ratio }\end{array}$} & \multirow[t]{2}{*}{ BHSA } \\
\hline & $\begin{array}{l}\text { Bearer } \\
\text { Rate } \\
\text { (Kbps) }\end{array}$ & $\begin{array}{c}\text { PPP } \\
\text { Session } \\
\text { Time (s) }\end{array}$ & $\begin{array}{c}\text { PPP } \\
\text { Session } \\
\text { Duty Ratio }\end{array}$ & BLER & $\begin{array}{c}\text { Throughput/ } \\
\text { session }\end{array}$ & $\begin{array}{l}\text { Bearer } \\
\text { Rate } \\
\text { (Kbps) }\end{array}$ & $\begin{array}{c}\text { PPP } \\
\text { Session } \\
\text { Time (s) }\end{array}$ & $\begin{array}{c}\text { PPP } \\
\text { Session } \\
\text { Duty Ratio }\end{array}$ & BLER & $\begin{array}{c}\text { Throughput } \\
\text { /session }\end{array}$ & & \\
\hline Voip & 26.9 & 80 & 0.4 & $1 \%$ & 869.495 & 26.9 & 80 & 0.4 & $1 \%$ & 869.495 & 2 & 0.1 \\
\hline Video Phone & 62.53 & 70 & 0.2 & $1 \%$ & 884.263 & 62.53 & 70 & 0.2 & $1 \%$ & 884.263 & 2 & 0.1 \\
\hline Video Conference & 62.53 & 500 & 0.1 & $1 \%$ & 3158.081 & 62.53 & 500 & 0.1 & $1 \%$ & 3158.081 & 2 & 0.1 \\
\hline Real Time Gaming & 31.26 & 1800 & 0.5 & $1 \%$ & 28418.182 & 125.06 & 1800 & 0.8 & $1 \%$ & 181905.455 & 15 & 1.2 \\
\hline Straming media & 31.26 & 1800 & 0.1 & $1 \%$ & 5683.636 & 250.11 & 1800 & 0.9 & $1 \%$ & 409270.909 & 13 & 1 \\
\hline IMS Signaling & 15.63 & 7 & 0.2 & $1 \%$ & 22.103 & 15.63 & 7 & 0.2 & $1 \%$ & 22.103 & 20 & 4 \\
\hline Web Browsing & 62.53 & 1800 & 0.05 & $1 \%$ & 5684.545 & 250.11 & 1800 & 0.05 & $1 \%$ & 22737.273 & 15 & 2 \\
\hline File Transfer & 140.69 & 600 & 1 & $1 \%$ & 85266.667 & 750.34 & 600 & 0.5 & $1 \%$ & 227375.758 & 1 & 0.2 \\
\hline Email & 140.69 & 50 & 0.5 & $1 \%$ & 3552.778 & 750.34 & 50 & 0.5 & $1 \%$ & 18947.980 & 3 & 1 \\
\hline P2P File Sharing & 250.11 & 60 & 0.1 & $1 \%$ & 1515.818 & 750.34 & 60 & 0.1 & $1 \%$ & 4547.515 & 1 & 0.4 \\
\hline
\end{tabular}

Selanjutnya adalah mengitung single user thoughput dengan rumus berikut: [10]

Single User Throughput $=\frac{\left[\sum \frac{\text { throughput }}{\text { sesion }}\right] \times B H S A x \text { Penetration ratio } x(1+P A R)}{3600}$

Dimana, BHCA adalah Busy hour Call Attempt, penetration rate merupakan nilai penetrasi layanan dan PAR adalah Peak to Average Ratio sebesar 10\%

Tabel 5. Single Service Throughput LTE

\begin{tabular}{|l|r|r|}
\hline Single User Throughput (kbit) & $865,721.46$ & $10,322,209.58$ \\
\hline Single User Throughput (kbps) & 240.48 & $2,867.28$ \\
\hline
\end{tabular}

Setelah kita mendapatkan single user thrpughput, maka selanjutnya akan kita hitung total dari kebutuhan jaringan LTE yaitu mengkalikan single user thoughput dengan jumlah pelanggan potensial LTE dan parameter busy hour. Parameter busy hour yang digunakan antara lain proporsi total trafik dari hari sibuk dalam satu tahun, Proporsi trafik jam sibuk dalam hari sibuk dan proporsi trafik 1 hari sibuk terhadap total trafik hari sibuk setahun, sehingga didapatkan hasil perhitungan seperti pada tabel dibawah ini:

Tabel 6. Demand Subscriber total

\begin{tabular}{|l|r|r|}
\hline Demand subscriber total (Kbps) & $39,862.51$ & $475,290.44$ \\
\hline Demand subscriber total (Mbps) & 39.86 & 475.29 \\
\hline
\end{tabular}

3. Perhitungan kapasitas sel

Untuk dapat mengetahui kebutuhan kapasitas informasi dalam satu e_NodeB, maka dibutuhkan perhitungan data rate sesuai dengan modulasi dan bandwidth yang digunakan. Persamaan di bawah ini menunjukkan rumus untuk menghitung data rate, yaitu : [2]

$$
N_{R E}=\frac{N_{\text {subcarrier }} \times N_{\text {symbol }} \times \text { Subframe } T s \times N_{R B}}{\text { Subframe Rate }}
$$


Dimana :

$\begin{array}{ll}\mathrm{N}_{\mathrm{RE}} & \text { : jumlah RE (Resource Element) } \\ \mathrm{N}_{\text {subcarrier }} & \text { : jumlah subcarrier } \\ \mathrm{N}_{\text {symbol }} & \text { : jumlah simbol OFDM tiap subframe } \\ \text { Subframe Ts } & \text { : jumlah timeslot yang ada untuk } 1 \text { subframe LTE (2 Ts) } \\ \text { Subframe Rate } & \text { : durasi dari transmisi untuk 1 subframe LTE (1 ms) } \\ \mathrm{N}_{\mathrm{RB}} & \text { : jumlah RB (Resource Block) untuk bandwidth tertentu }\end{array}$

Maka didapatkan kapasitas sel seperti pada tabel dibawah ini:

Tabel 7. Data rate per modulation dan coding dan Nilai SINR Berdasarkan MCS

\begin{tabular}{|l|r|r|r|c|c|}
\hline $\begin{array}{l}\text { Modulation And } \\
\text { Coding }\end{array}$ & bit/ & \multicolumn{2}{|c|}{ Data Rate } & \multicolumn{2}{c|}{ SINR } \\
\cline { 3 - 6 } & symbol & $\mathbf{1 0 ~ \mathbf { ~ M z }}$ & $\mathbf{1 5} \mathbf{~ M H z}$ & Uplink & downlink \\
\hline \hline QPSK 1/2 & 1 & 8.4 & 12.6 & -7 & -7 \\
\hline QPSK 2/3 & 1.33 & 11.17 & 16.76 & -2 & -2 \\
\hline QPSK 3/4 & 1.5 & 12.6 & 18.9 & 4 & 4 \\
\hline 16QAM 1/2 & 2 & 16.8 & 25.2 & 6,5 & 6,5 \\
\hline 16QAM 2/3 & 2.67 & 22.43 & 33.64 & 8 & 8 \\
\hline 16QAM 3/4 & 3 & 25.2 & 37.8 & 10 & 10 \\
\hline 64QAM 2/3 & 4 & 33.6 & 50.4 & & 13,5 \\
\hline 64QAM 3/4 & 4.5 & 37.8 & 56.7 & & 15 \\
\hline 64QAM 4/5 & 4.8 & 40.32 & 60.48 & & 17 \\
\hline 64QAM 5/6 & 5 & 42 & 63 & & 18 \\
\hline
\end{tabular}

Nilai SINR pada tabel di gunakan untuk menghitung persentase distribusi MCS dengan menggunakan pedekatan coverage propagasi okumura hata untuk menentukan radius jangkauan berdasarkan MCS masing-masing. Kemudian dikalikan dengan data rate berdasarkan bandwidth yang digunakan yaitu $10 \mathrm{MHz}$ dan $15 \mathrm{MHz}$.

Tabel 8. Kapasitas Sel (a) bandwidth $10 \mathrm{MHz}$ (b) bandwidth $15 \mathrm{MHz}$

\begin{tabular}{|c|c|c|c|c|c|}
\hline \multirow[b]{2}{*}{ MCS } & \multirow{2}{*}{$\begin{array}{c}\text { Data } \\
\text { Rate } \\
\text { (Mbps) }\end{array}$} & \multicolumn{2}{|c|}{$\begin{array}{c}\text { Persentase Distribusi } \\
(\%)\end{array}$} & \multicolumn{2}{|c|}{ Kapasitas (Mbps) } \\
\hline & & UL & $\mathrm{DL}$ & UL & $\mathrm{DL}$ \\
\hline QPSK $1 / 2$ & 8.4 & 34.47 & 28.62 & 2.89548 & 2.40408 \\
\hline QPSK $2 / 3$ & 11.17 & 22.66 & 18.81 & 2.531122 & 2.101077 \\
\hline QPSK 3/4 & 12.6 & 13.7 & 11.37 & 1.7262 & 1.43262 \\
\hline 16 QAM $1 / 2$ & 16.8 & 11.1 & 9.22 & 1.8648 & 1.54896 \\
\hline 16 QAM 2/3 & 22.43 & 9.79 & 8.13 & 2.195897 & 1.823559 \\
\hline 16 QAM 3/4 & 25.2 & 8.28 & 6.87 & 2.08656 & 1.73124 \\
\hline 64 QAM 2/3 & 33.6 & & 5.12 & & 1.72032 \\
\hline 64 QAM 3/4 & 37.8 & & 4.52 & & 1.70856 \\
\hline 64 QAM 4/5 & 40.32 & & 3.82 & & 1.540224 \\
\hline 64 QAM 5/6 & 42 & & 3.51 & & 1.4742 \\
\hline \multicolumn{2}{|c|}{ total } & 100 & 100 & 13.30 & 11.04 \\
\hline \multicolumn{4}{|c|}{ Kapasitas Site (3 sektor) } & 39.90 & 33.12 \\
\hline \multicolumn{4}{|c|}{ Kapasitas Site dengan MIMO $2 \times 2$} & 79.80 & 66.25 \\
\hline \multicolumn{4}{|c|}{ Kapasitas Site dengan MIMO $3 \times 3$} & 119.70 & 99.37 \\
\hline
\end{tabular}

\begin{tabular}{|c|c|c|c|c|c|}
\hline \multirow[b]{2}{*}{ MCS } & \multirow{2}{*}{$\begin{array}{c}\text { Data } \\
\text { Rate } \\
\text { (Mbps) }\end{array}$} & \multicolumn{2}{|c|}{$\begin{array}{l}\text { Persentase Distribusi } \\
(\%)\end{array}$} & \multicolumn{2}{|c|}{ Kapasitas (Mbps) } \\
\hline & & UL & $\mathrm{DL}$ & UL & DL \\
\hline QPSK $1 / 2$ & 12.6 & 34.47 & 28.62 & 4.34322 & 3.60612 \\
\hline QPSK 2/3 & 16.76 & 22.66 & 18.81 & 3.797816 & 3.152556 \\
\hline QPSK 3/4 & 18.9 & 13.7 & 11.37 & 2.5893 & 2.14893 \\
\hline 16 QAM $1 / 2$ & 25.2 & 11.1 & 9.22 & 2.7972 & 2.32344 \\
\hline 16 QAM 2/3 & 33.64 & 9.79 & 8.13 & 3.293356 & 2.734932 \\
\hline 16 QAM 3/4 & 37.8 & 8.28 & 6.87 & 3.12984 & 2.59686 \\
\hline 64 QAM 2/3 & 50.4 & & 5.12 & & 2.58048 \\
\hline 64 QAM 3/4 & 56.7 & & 4.52 & & 2.56284 \\
\hline 64 QAM 4/5 & 60.48 & & 3.82 & & 2.310336 \\
\hline 64 QAM 5/6 & 63 & & 3.51 & & 2.2113 \\
\hline \multicolumn{2}{|l|}{ total } & 100 & 100 & 19.95 & 16.56 \\
\hline \multicolumn{4}{|c|}{ Site capacity (3 sektor) } & 59.85 & 49.69 \\
\hline \multicolumn{4}{|c|}{ Kapasitas Site dengan MIMO $2 \times 2$} & 119.70 & 99.38 \\
\hline \multicolumn{4}{|c|}{ Kapasitas Site dengan MIMO $3 \times 3$} & 179.56 & 149.07 \\
\hline
\end{tabular}

Pada tabel merupakan hasil perhitungan Kapasitas site dengan menggunakan beberapa asumsi yaitu, penggunaan 3 sektor pada masing-masing site serta penggunaan antenna MIMO $2 \times 2$ dan MIMO $3 \times 3$.

\section{ANALISA DAN HASIL SIMULASI}

\subsection{Hasil Perencanaan Jaringan Seluler Dengan Pendekatan Cakupan}

Untuk menghitung jumlah e_NodeB yang dibutuhkan di wilayah sub-urban dan rural Kabupaten Banyumas berdasarkan cakupan area, terlebih dahulu kita harus menghitung nilai pathloss, jari-jari dan luas sel. 
Tabel 9. Parameter Link Budget LTE frekuensi $700 \mathrm{MHz}$

\begin{tabular}{|c|c|c|c|c|c|}
\hline \multicolumn{3}{|c|}{ Uplink Parameter } & \multicolumn{3}{|c|}{ Downlink Parameter } \\
\hline Parameter & Nilai & Satuan & Parameter & Nilai & Satuan \\
\hline \multicolumn{3}{|l|}{ Transmitter - UE } & \multicolumn{3}{|l|}{ Transmitter - eNode B } \\
\hline Tx Power & 23 & $\mathrm{dBm}$ & Tx Power & 46 & $\mathrm{dBm}$ \\
\hline Tx Antenna Gain & 0 & $\mathrm{dBi}$ & Tx Antenna Gain & 18 & $\mathrm{dBi}$ \\
\hline Body Loss & 0 & $\mathrm{~dB}$ & Cable Loss & 2 & $\mathrm{~dB}$ \\
\hline EIRP & 23 & $\mathrm{dBm}$ & EIRP & 62 & $\mathrm{dBm}$ \\
\hline \multicolumn{3}{|l|}{ Receiver - eNode B } & \multicolumn{3}{|l|}{ Receiver - UE } \\
\hline Noise Figure & & $\mathrm{dB}$ & Noise Figure & 7 & $\mathrm{~dB}$ \\
\hline Thermal noise & -132 & $\mathrm{~dB}$ & Thermal noise & -132 & $\mathrm{~dB}$ \\
\hline Receiver noise & -130 & $\mathrm{~dB}$ & Receiver noise & -125 & $\mathrm{~dB}$ \\
\hline Rx SINR & -7 & $\mathrm{~dB}$ & Rx SINR & -9 & $\mathrm{~dB}$ \\
\hline Rx sensitivity & -137 & $\mathrm{~dB}$ & Rx sensitivity & -134 & $\mathrm{~dB}$ \\
\hline Inteference Margin & 1 & $\mathrm{~dB}$ & Interference Margin & 4 & $\mathrm{~dB}$ \\
\hline Cable Loss & 2 & $\mathrm{~dB}$ & Control Channel Overhead & & $\mathrm{dB}$ \\
\hline \multirow[t]{2}{*}{ Rx Antenna Gain } & 18 & $\mathrm{dBi}$ & Rx Antenna gain & & $\mathrm{dB}$ \\
\hline & & & Body Loss & & $\mathrm{dB}$ \\
\hline MAPL & 175.2 & $\mathrm{~dB}$ & MAPL & 191.2 & $\mathrm{~dB}$ \\
\hline
\end{tabular}

Ada beberapa nilai yang perlu diasumsikan, untuk Kabupaten Banyumas yang termasuk dalam area urban, maka tinggi antena UE $1,5 \mathrm{~m}(0,0015 \mathrm{~km})$, tinggi antena BS $50 \mathrm{~m}(0,05 \mathrm{~km})$ dan faktor koreksi tinggi antenna $\mathrm{CH}=4,87$

Nilai jari-jari sel dihitung berdasarkan arah uplink dan downlink dengan menggunakan nilai MAPL masing-masing arah. Berdasarkan substitusi persamaan (6) didapatkan rumus untuk mencari nilai jari-jari. Setelah mendapatkan nilai jari-jari sel, selanjutnya menghitung luas sel berdasarkan arah uplink dan downlink. Mengacu pada persamaan (7). Maka akan kita dapatkan kebutuhan site berdasarkan cakupan (coverage) dengan membagi Luas wilayah dengan Luas sel sehingga didapatkan hasil sebagai berikut:

Tabel 10. Hasil Perhitungan radius, luas dan jumlah e_NodeB LTE Frekuensi $700 \mathrm{MHz}$

\begin{tabular}{|l|l|l|l|}
\hline Arah komunikasi & Distance $(\mathrm{Km})$ & Luas cell $\left(\mathrm{Km}^{2}\right)$ & Jumlah e_NodeB \\
\hline Uplink & 2,18 & 24,2 & 53 \\
\hline Downlink & 4,35 & 96,1 & 13 \\
\hline
\end{tabular}

\subsection{Hasil Perencanaan Jaringan Seluler Dengan Pendekatan Kapasitas}

Perencanaan e_NodeB berdasarkan kapasitas dilakukan dengan cara membagi kapasitas maksimum site e_NodeB dengan total demand subscriber berdasarkan bandwidth dan teknologi antenna yang digunakan.

Perancangan e_NodeB pada bandwidth $15 \mathrm{MHz}$ memiliki kapasitas lebih besar daripada bandwidth $10 \mathrm{MHz}$ sehingga menghasilkan jumlah sebaran e_NodeB lebih sedikit yaitu 5 e_NodeB berbanding 8 e_NodeB dengan menggunakan antenna MIMO 2X2. Sedangkan penggunkaan antenna MIMO 3X3 menghasilkan jumlah yang sama, yaitu 4 e_NodeB baik bandwidth $10 \mathrm{MHz}$ maupun $15 \mathrm{MHz}$.

Tabel 11. Hasil Perhitungan Jumlah e_NodeB LTE Frekuensi 700 MHz dengan pendekatan kapasitas

\begin{tabular}{|l|l|l|}
\hline $\begin{array}{l}\text { Jenis } \\
\text { antenna }\end{array}$ & $\begin{array}{l}\text { Jumlah e-Node B B } \\
\text { Bandwidth 10 MHz }\end{array}$ & $\begin{array}{l}\text { Jumlah e-Node B B } \\
\text { Bandth 15 MHz }\end{array}$ \\
\hline MIMO 2x2 & 8 & 5 \\
\hline MINO 3x3 & 4 & 4 \\
\hline
\end{tabular}




\subsection{Hasil Simulasi dengan Software Atoll}

Pada simulasi perencanaan LTE dengan menggunakan softwareAtoll, dilakukan dengan 2 skenario penggelaran, yaitu menggunakan bandwidth $10 \mathrm{MHz}$ pada frekuensi $700 \mathrm{MHz}$ dan bandwidth $15 \mathrm{MHz}$ pada frekuensi $10 \mathrm{MHz}$. Dimana tujuan dari perancanaan ini untuk menganalisa perbandingan parameter performa jaringan LTE pada kedua skenario tersebut, yaitu RSPP, SINR, Radio bearer dan Throughput.

Dengan menggunakan parameter link budget yang sama, baik pada skenario bandwidth $10 \mathrm{MHz}$ maupun $15 \mathrm{MHz}$ menghasilkan 13 e_NodeB yang mencakupi seluruh wilayah rural dan sub-urban banyumas.

\section{RSRP}

Pada gambar memperlihatkan sebaran RSRP atau kuat sinyal yang dihasilkan oleh masing-masing transmitter e_NodeB. Kuat sinyal yang dipancarkan baik pada bandwidth 10 $\mathrm{MHz}$ dan $15 \mathrm{MHz}$ memiliki nilai yang sama. Dimana rata-rata menghasilkan RSRP sebesar -72.2 dB. Cakuapan wilayah kuat sinyal yang yang memiliki kualitas "very good" mencapai $953 \mathrm{Km} 2$ atau sekitar $66 \%$ dari luas wilayah sub-urban dan rural Kabupaten Banyumas, seperti yang dilustrasikan pada histogram Gambar 2.
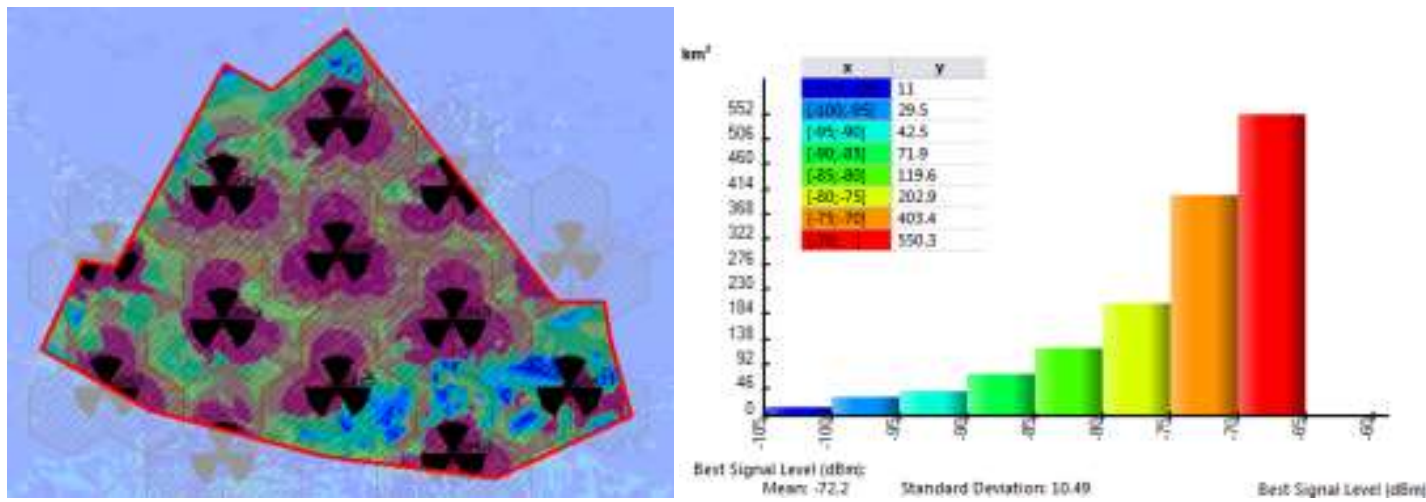

Gambar 2. Sebaran dan Histogram persentase RSRP bandwidth $10 \mathrm{MHz}$ dan $15 \mathrm{MHz}$

Dari hasil sebaran RSRP dapat disimpulkan bahwa secara kuat sinyal wilayah sub-urban dan rural kabupaten Banyumas mampu medapatkan kualitas sinyal yang cukup baik dimana hanya sebagian kecil area yang medapatkan kualitas yang jelak yaitu $0.7 \%$ dari luas wilayah pengamatan.

\section{SINR}

Dari hasil simulasi perhitungan SINR pada kedua skenarion menunjukan hasil yang sama, dimana perbandingan sinyal dan noise menghasilkan nilai rata-rata $6.83 \mathrm{~dB}$. Hal ini menunjukan bahwa nilai tersebut masih berada pada batas ambang normal kualitas.
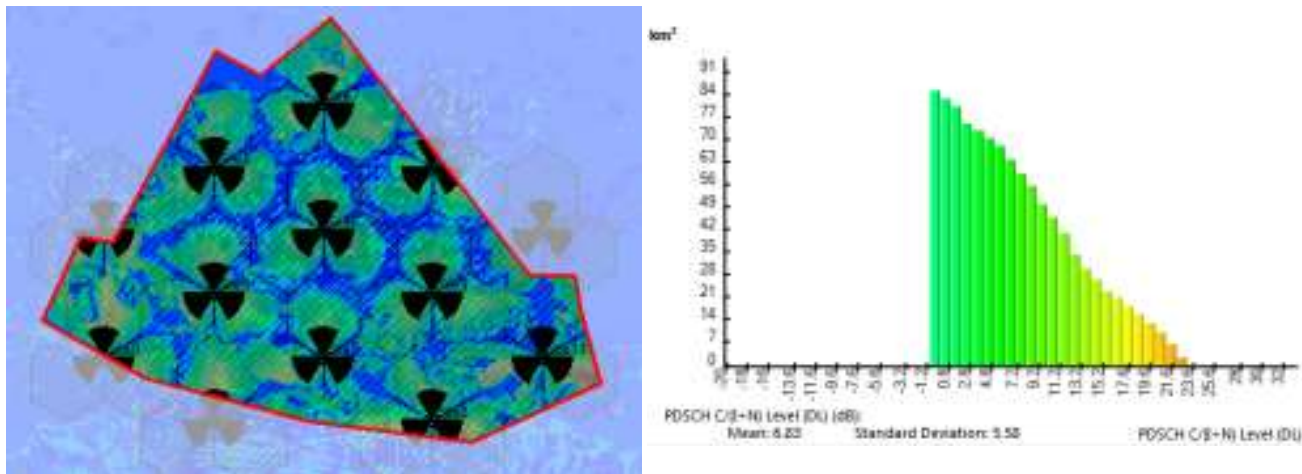

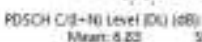


Pada histogram pada gambar 6, menunjukan bahwa $7.5 \%$ wilayah pengamatan mendapatkan kualitas SINR yang baik sedangkan $92.5 \%$ berada pada batas ambang normal.

\section{Radio bearer}

Pada simulasi menggunakan softwareAtoll, Kualitas Radio bearer pada cakupan wilayah sub-urban dan rural kabupaten Banyumas ditunjukan pada parameter Service Area Analysis. Perhitungan service area analysis menunjukan nilai CQI index sebesar 7.17. sehingga rata-rata pada wilayah pengamatan hanya menggunakan modulasi 64QAM dengan code rate 466 dan efisiensi 2.73, sesuai dengan Tabel 3.
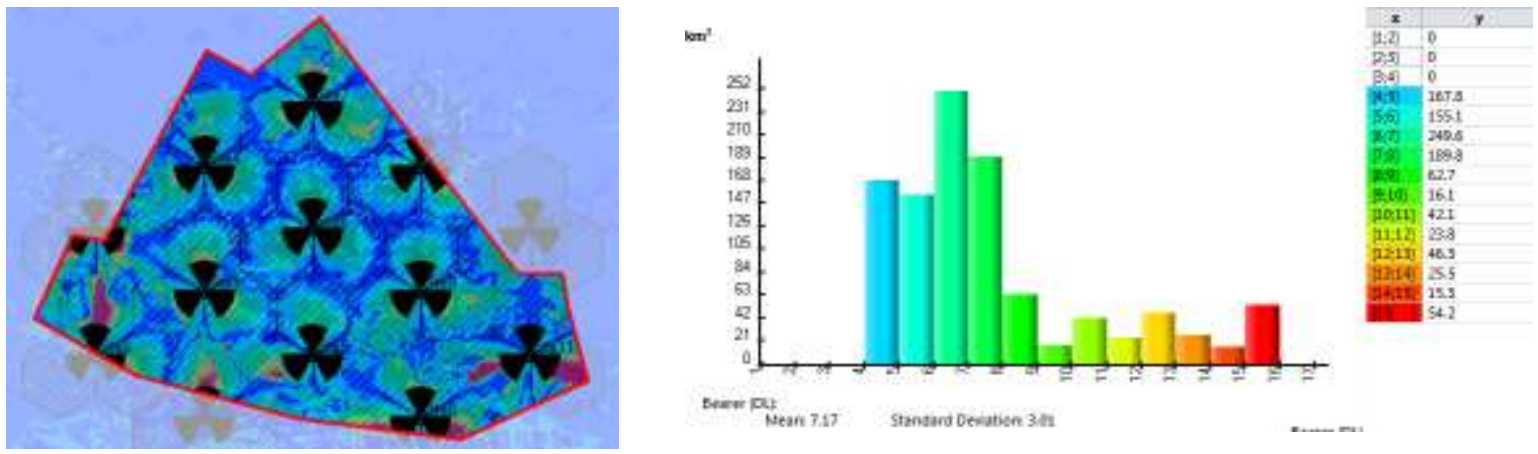

Gambar 4. Sebaran dan Histogram persentase Radio bearer bandwidth $10 \mathrm{MHz}$ dan $15 \mathrm{MHz}$

Berdasarkan histogram gambar Beberapa wilayah dapat nilai CQI index hingga 15, artinya wilayah tersebut mendapatkan layanan dengan modulasi 256QAM, code rate 948 dan efisiensi 7.41.

\section{Throughput}

Parameter throughput merupakan besaran kecepatan data yang dapat diakses oleh pengguna jaringan LTE di wilayah pengamatan. Terdapat perbedaaan hasil throughput pada 2 skenario yang digunakan. Dimana pada skenario bandwidth $10 \mathrm{MHz}$ menghasilkan throughput maksimum sebesar 16 Mbps dengan rata throughput sebesar 4.8 Mbps. Sedangkan, pada skenario bandwidth 15 Mbps mampu mengasilkan throughput maksimal sebesar 52 Mbps dan rata rata throughput sebesar $49.5 \mathrm{Mbps}$. Kedua skenario menggunakan teknologi antenna Multi User MIMO pada downlink dan receive diversity pada uplink.

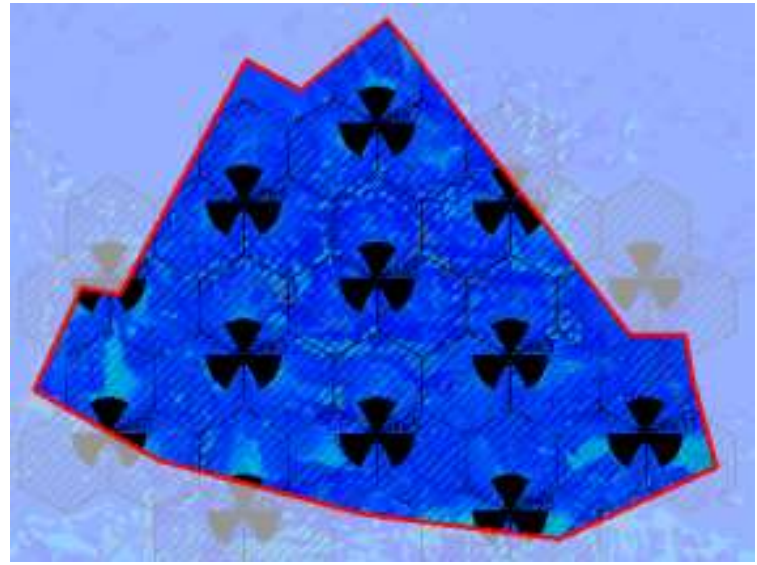

(a)

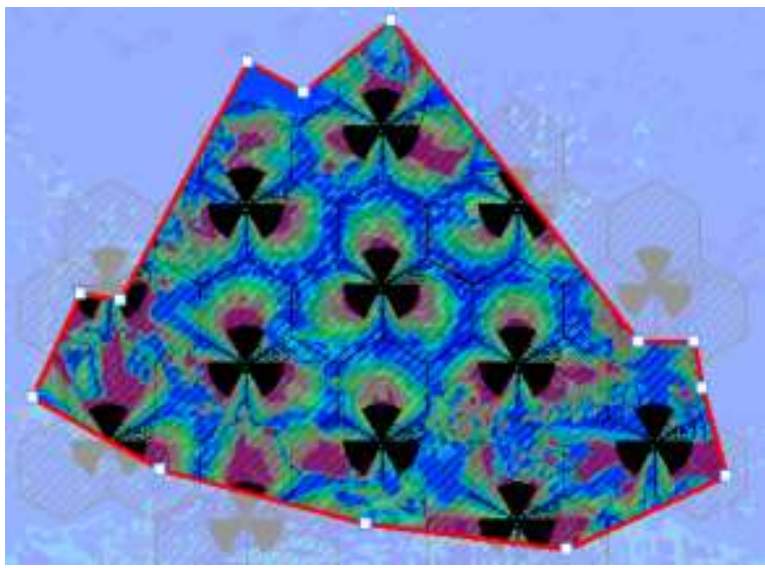

(b)

Gambar 5. Sebaran Throughput (a) bandwidth $10 \mathrm{MHz}$ (b) bandwidth $15 \mathrm{MHz}$ 
Bila dibandingkan dengan perhitungan berdasarkan teori terbapat berbedaan nilai yang signifikan pada skenario bandwidth $10 \mathrm{MHz}$, dimana berdasarakan perhitungan teori menghasilkan nilai maksimal throughput adalah 66 Mbps (MIMO 2X2) dan 99 Mbps (MIMO 3X3). Sedangkan pada bandwidth $15 \mathrm{MHz}$ menghasilkan nilai maksimal throughput adalah 99 mbps (MIMO 2X2) dan 149 Mbps (MIMO 3X3).

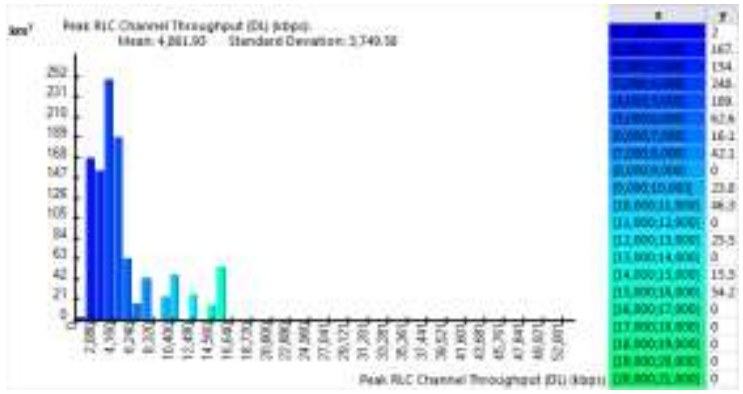

(a)

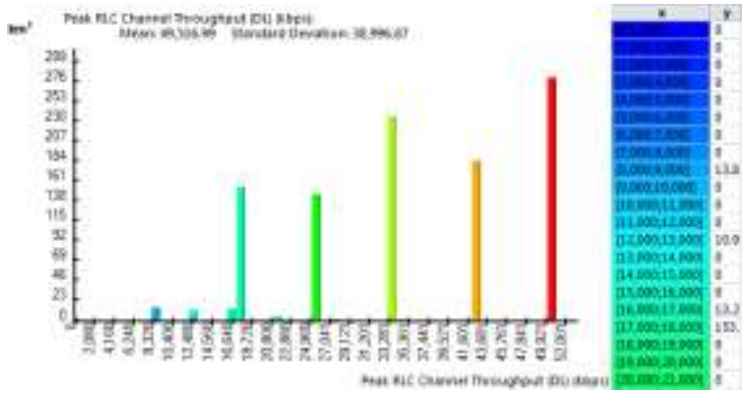

(b)

Gambar 6. Histogram persentase Throughput (a) Bandwidth $10 \mathrm{MHz}$ (b) Bandwidth $15 \mathrm{MHz}$

Hal ini dapat disimpulkan bahawa penggunaa Bnadwidth $15 \mathrm{MHz}$ mampu memberikan kecepatan data rate yang lebih baik, namun hal tersebut tergantung kepada ketersediann bandwidth yang dimiliki oleh suatu operator telekomunikasi yang ingin menggelar LTE di wilayah sub-urban dan rural kabupaten Banyumas.

\section{KESIMPULAN}

Pada Penelitian Perancangan dan Analisa Penggelaran LTE Pada Frekuensi $700 \mathrm{MHz}$ Dengan Metode Adaptif Modulation Coding Untuk Implementasi Digital Dividend di Wilayah Sub-Urban dan Rural Kabupaten Banyumas dengan menggunakan bandwidth $10 \mathrm{MHz}$ dan 15 $\mathrm{MHz}$, diperoleh kesimpulan sebagai berikut:

1. Pada perhitungan berdasarkan teori pendekatan coverage, dihasilkan 13 eNode. Hal tersebut sama dengan jumlah e_NodeB yang dihasilkan berdasarkan simulasi softwareAtoll.

2. Pada perhitungan berdasarkan teori pendekatan kapasitas mengasilkan nilai yang berbeda berdasarkan bandwidth yang digunakan dan teknologi antenna yang digunakan. Pada bandwith $10 \mathrm{MHz}$ membutuhkan 8 e_NodeB (MIMO 2x2) dan 4 e_NodeB (MIMO 3x3). Sedangkan pada Pada bandwith $15 \mathrm{MHz}$ membutuhkan 4 e_NodeB baik menggunakan MIMO 2x2 maupun MIMO 3x3.

3. Dari kedua skenario bandwidth $10 \mathrm{MHz}$ dan $15 \mathrm{MHz}$ menghasilkan jumlah e_NodeB, pola radiasi dan kuat sinyal yang sama dengan rata-rata RSRP sebesar $-72.2 \mathrm{~dB}$. Hal ini dikarenakan kedua skenario menggunakan parameter link budget yang sama, sehingga tidak mempengaruhi kualitas sinyal pada 13 eNode yang dirancang.

4. Pada perhitungan simulasi SINR dan radio bearer menunjukan bahwa kedua skenario nilai yang sama. Dimana kualitas SINR rata-rata berada pada level normal sebesar $6.83 \mathrm{~dB}$ dan kualitas radio bearer yang di representasikan pada nilai CQI index sebesar 7.17 sehingga perangkat user yang mampu menerima layanan adalah yang memiliki spesifikasi modulasi 64QAM dengan code rate 466 dan efisiensi 2.7.

5. Pada perhitungan simulasi thrpughput, menghasilkan nilai yang berbeda tergantung pada penggunaan bandwidth. Pada bandwidth $10 \mathrm{MHz}$ menghasilkan throughput maksimal sebesar 16 Mbps dan $15 \mathrm{MHz}$ mengasilkan throughput maksimal 52 Mbps. 


\section{DAFTAR PUSTAKA}

[1] Setiawan, Denny. 2013. Pemodelan Akselerasi Implementasi Digital Dividend di Indonesia. Disertasi Universitas Indonesia. Jakarta.

[2] Wahyudin, Ade. Muayyadi, Ali. Mufti A, Nachwan dan Hasan, Taufik. 2013. Planning and Techno-Economy Analysis of UMTS to LTE Migration at Frequency $700 \mathrm{MHz}$ in DKI Jakarta. Proceeding SITIA ITS. Surabaya.

[3] Saputra, Riza. 2009. Kajian Tekno-Ekonomi Penggelaran Teknologi Long Term Evolution (LTE) di Kota Bandung. Institut Teknologi Bandung.

[4] Hikmaturokhman, Alfin. Wardana, Lingga. Fernando, Brian. Mhardika, Gita dan Dharmanto, Satriyo. 2015. 4G Handbook Versi Bahasa Indonesia Jilid 2. www.nulisbuku.com. Jakarta.

[5] Kawser, Mohammad T. Hamid, Nafiz Imtiaz Bin. Hasan, Md Nayeemul. Shah Alam, M. dan Rahman, Musfiqur. 2012. Downlink SNR to CQI Mapping for Different Multiple Antenna Techniqus in LTE. International Journal of Information and Electronics Engineering. 2:5 757.

[6] 4G Americas . 2012 The Benefit of Digital Deviden. [Online] Available at: http://www.4gamericas.org/en/newsroom/press-releases/benefits-digital-dividendamericas/ [diakses pada tanggal 24 Agustus 2016].

[7] Badan Pusat Statistik Kabupaten Banyumas. 2015. Kabupaten Banyumas Dalam Angka 2015. BPS kabupaten Banyumas.

[8] H, Holma dan A, Toskala. 2010 WCDMA for UMTS: HSPA Evolution and LTE, John Wiley \& Sons.

[9] PT. Telekomunikasi Indonesia. 2016 “Annual Report 2015” . [Online] Available at: http://www.telkomsel.com/media/upload/annualreport/AR_TSEL2015.pdf [diakses pada tanggal 24 Agustus 2016].

[10] Huawei. 2016. LTE Radio Network Planning Introduction [Online] Available at: http://documents.mx/documents/11-lte-radio-network-planning-introduction-

5584605a4eb1b.html [diakses pada tanggal 26 September 2016] 